\title{
Comparison between Intraperitoneal Instillation of Bupivacaine Versus Dexmedetomidine for Post-Operative Analgesia after Laparscopic Cholecystectomy
}

\author{
YOMNA M. EL-BAHNASSY, M.Sc.; KAMAL EL-DEIN A. HEIKAL, M.D.; \\ NABIL A.M. EL-SHEIKH, M.D. and REHAB S. EL-KALLA, M.D.
}

The Department of Anesthesiology and Surgical ICU, Faculty of Medicine, Tanta University

\begin{abstract}
Background: Optimizing post-operative pain management can be challenging due to surgical factors and intrinsic patient responses to surgery and pain. Intraperitoneal instillation of local anesthetic drugs has become a popular practice for pain relief after laparoscopic surgery which limit the requirements for opioid analgesics and prevent common post-operative side effects such as ileus, nausea and vomiting, thus enables more patients to meet early discharge criteria.
\end{abstract}

Aim of Study: The aim is to compare between the efficacy of intraperitoneal instillation of Bupivavcine versus Dexmedetomedine for pain relief post-operatively after Laparoscopic Cholecystectomy.

Patient and Methods: This study was carried out on 75 patients, 18-59 years, ASA I or II scheduled for elective Laparoscopic Cholecystectomy. Patients were randomly assigned to receive either Dexmedetomidine (DEX ), Bupivacaine (Bup), or normal saline (control group) for post laparoscopic cholecystectomy peritoneal instillation of local anesthetic. All patients were premedicated with IV fentanyl inj. $(2 \mu \mathrm{g} / \mathrm{kg})$ $15 \mathrm{~min}$ before induction of anesthesia. The induction was done with propofol $2 \mathrm{mg} / \mathrm{kg}$ IV and to facilitate the endotracheal intubation, atracurium $(0.5 \mathrm{mg} / \mathrm{kg})$ was given intravenously. Throughout the procedure controlled ventilation was maintained with $100 \% \mathrm{O}_{2}$, sevoflurane (1-2\%) and atracurium. At the end of the surgery, the study solution was instillated intraperitoneally before removal of trocar in Trendelenberg's position, into the hepato-diaphragmatic space, on gall bladder bed and near and above hepatoduodenal ligament. The neuromuscular blockade was antagonized with neostigmine 0.05 $\mathrm{mg} / \mathrm{kg}$ and atropine $0.01 \mathrm{mg} / \mathrm{kg}$ and trachea was extubated.

Recording the demographic data, duration of surgery, intensity of post-operative pain using VAS score, pattern of pain, analgesic requirement, time to the first request of analgesia, total dose of analgesia and side effects.

Correspondence to: Dr. Yomna M. El-Bahnassy, The Department of Anesthesiology and Surgical ICU, Faculty of Medicine, Tanta University
Results: VAS score was significantly lower in Group I (DEX) than Group II (Bup) and Group III (Control) at 30min, $1 \mathrm{hr}, 2 \mathrm{hr}$ and $4 \mathrm{hr}$ after extubation $(p$-value $<0.05$ ). The onset of post-operative analgesia was significantly lower in Group II (Bup) and Group III (Control) than Group I (DEX) ( $p$-value $<0.05)$. Total dose of post-operative analgesia requirement was significantly lower in Group I (DEX) and Group II (Bup) than in Group III (Control) ( $p$-value $<0.05)$.

Conclusions: Intraperitoneal instillation of dexmedetomidine $1 \mu / \mathrm{kg}$ in elective laparoscopic cholecystectomy significantly reduces the post-operative pain and significantly reduces the analgesic requirement in post-operative period as compared to bupivacaine $0.25 \%$ before removal of trocars at the end of surgery.

Key Words: Dexmedetomidine - Laparoscopic - Cholecystectomy-Bupivacaine.

\section{Introduction}

CURRENTLY the most accepted surgical technique for cholelithiasis is laparoscopic cholecystectomy as opposed to open cholecystectomy [1] The advantages of laparoscopic procedures over open procedures is lesser haemorrhage, better cosmetic results, lesser post-operative pain, and shorter recovery time, leading to shorter hospital stay and less expenditure [2]. Joris and colleagues reported that after laparoscopic cholecystectomy, visceral pain predominates in the first $24 \mathrm{~h}$ but subsides from a peak soon after operation, whereas shoulder pain, minor on the first day, increases and becomes significant on the following day [3] The ideal post-operative analgesic regimen should provide good analgesia, be cost-effective and have a low incidence of side effects [4]. Dexmedetomidine, the pharmacologically active d-isomer of medetomidine, it is a potent and highly selective a2-adrenoreceptor agonist with sympatholytic, 
sedative, amnestic, anxiolytic, neuroprotective and analgesic properties [5]. Bupivacaine is the most widely used local anaesthetic drug, intraperitoneal instillation of it has become a popular practice for pain relief after laparoscopic surgery [6] as it causes blockade of free afferent nerve endings in peritoneum [7]

\section{Aim and objectives:}

The aim of this study is to compare between the efficacy of intraperitoneal instillation of Bupivavcine versus Dexmedetomedine for pain relief post-operatively after Laparoscopic Cholecystectomy.

\section{Patients and Methods}

This prospective study was conducted in the Gastrointestinal and Laparoscopic Surgery Unit, General Surgery Department, Tanta University Hospitals in the period between February 2017 and January 2018 on 75 patients of both sex, 1859 years old, ASA I or II scheduled for elective Laparoscopic Cholecystectomy were included in the study. Written informed consents were obtained from each patient and patient refusal, patient who were allergic to the study drugs, patients with severe cardiac, pulmonary, and neurological diseases, those in whom procedure had to be converted to open cholecystectomy and in whom abdominal drain was put were excluded from the study. Patients were randomly assigned to receive either dexmedetomidine $1 \mathrm{~g} / \mathrm{kg}$ in total volume of $50 \mathrm{ml}$ (DEX group: $\mathrm{n}=25$ ), Bupivacaine $0.25 \mathrm{mg} / \mathrm{kg}$ in total volume $50 \mathrm{ml}$ (Bupivacaine group: $\mathrm{n}=25$ ), or normal saline $50 \mathrm{ml}$ of normal saline (control group: $\mathrm{n}=25$ ) for post laparoscopic cholecystectomy peritoneal instillation of local anesthetic before removal of trocar at the end of surgery.

Pre-operative assessment by: History taking, clinical examination, ECG, and basal laboratory investigations (complete blood count, blood sugar, kidney function tests, liver function tests, coagulation profiles). They were asked to fast for at least 6 hours for solids and 2 hours for clear fluids before surgery.

All patients were premedicated with IV fentanyl inj. $(211 \mathrm{~g} / \mathrm{kg}) 15$ minutes before induction of anesthesia. The induction was done with propofol $2 \mathrm{mg} / \mathrm{kg}$ intravenously and to facilitate the endotracheal intubation, atracurium $(0.5 \mathrm{mg} / \mathrm{kg})$ was given intravenously. Throughout the procedure controlled ventilation was maintained with $100 \% \mathrm{O}_{2}$, sevoflurane (1-2\%) and atracurium. Intraoperative mon- itoring included ECG, NIBP, $\mathrm{SpO}_{2}$, end tidal carbon dioxide $\left(\mathrm{ETCO}_{2}\right)$ and Temperature. Patients were placed in $15-20^{\circ}$ reverse Trendelenberg's position with the the left side tilt position. During laparoscopy, intra-abdominal pressure was maintained $12-14 \mathrm{mmHg}$. The $\mathrm{CO}_{2}$ was removed carefully by manual compression of the abdomen at the end of the procedure with open trocar. At the end of the surgery, the study solution was instillated intraperitoneally before removal of trocar in Trendelenberg's position, into the hepato-diaphragmatic space, on gall bladder bed and near and above hepatoduodenal ligament. The neuro-muscular blockade was antagonized with neostigmine 0.05 $\mathrm{mg} / \mathrm{kg}$ and atropine $0.01 \mathrm{mg} / \mathrm{kg}$ and trachea was extubated. The nasogastric tube was removed, and the patient was shifted to Post-Anaesthesia Care Unit (PACU). All patients stayed in PACU for $2 \mathrm{~h}$ after the end of surgery. Patient transferred to ward according to criteria of discharge from PACU.

\section{Results}

There was no significant difference between both groups as regard demographic data (age, weight and sex) $p$-value $>0.05$.

By comparing VAS changes in the three groups at different times of measurements, VAS score was significantly lower in Group I (DEX) than Group II (Bup) and Group III (Control) at 30min, 1hr, $2 \mathrm{hr}$ and $4 \mathrm{hr}$ after extubation $(p$-value $<0.05)$. Fig. (1), Table (1).

The onset of post-operative analgesia was significantly lower in Group II (Bup) and Group III (Control) than Group I (DEX) ( $p$-value <0.05).

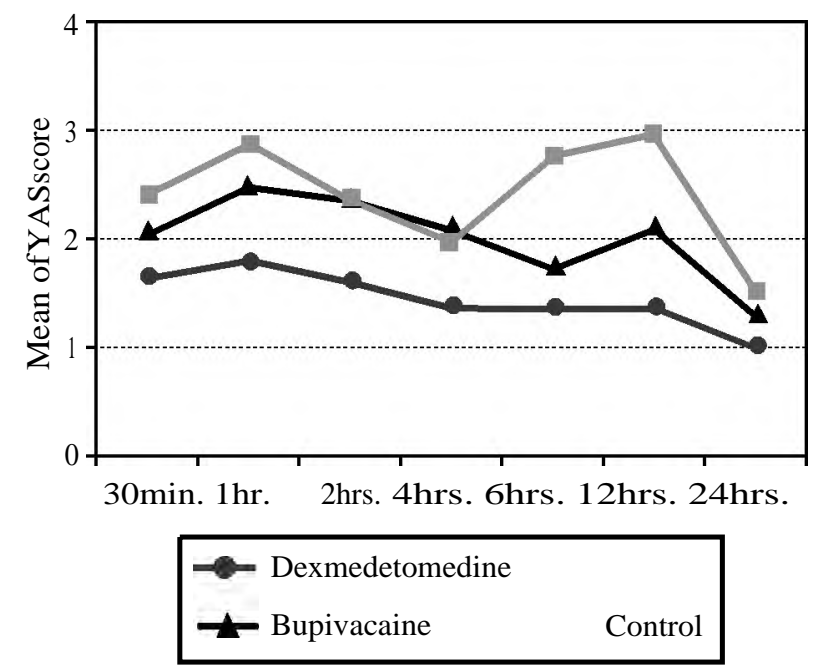

Fig. (1): Comparison between the three studied groups according to VAS score. 
Table (1): Comparison between the three studied groups according to VAS score.

\begin{tabular}{|c|c|c|c|c|c|c|c|}
\hline & \multicolumn{7}{|c|}{ VAS score } \\
\hline & $30 \mathrm{~min}$. & $1 \mathrm{hr}$. & $2 \mathrm{hrs}$. & $4 \mathrm{hrs}$. & $6 \mathrm{hrs}$. & $12 \mathrm{hrs}$. & $24 \mathrm{hrs}$. \\
\hline \multicolumn{8}{|l|}{ Dex: } \\
\hline Min. & 1.0 & 1.0 & 1.0 & 1.0 & 1.0 & 1.0 & 1.0 \\
\hline Max. & 2.0 & 2.0 & 2.0 & 2.0 & 3.0 & 3.0 & 1.0 \\
\hline Mean & 1.64 & 1.80 & 1.60 & 1.36 & 1.36 & 1.36 & 1.0 \\
\hline SD. & 0.49 & 0.41 & 0.50 & 0.49 & 0.70 & 0.70 & 0.0 \\
\hline Median & 2.0 & 2.0 & 2.0 & 1.0 & 1.0 & 1.0 & 1.0 \\
\hline \multicolumn{8}{|l|}{ Bup: } \\
\hline Min. & 2.0 & 2.0 & 2.0 & 1.0 & 1.0 & 1.0 & 1.0 \\
\hline Max. & 3.0 & 3.0 & 3.0 & 3.0 & 4.0 & 4.0 & 2.0 \\
\hline Mean & 2.04 & 2.48 & 2.36 & 2.08 & 1.72 & 2.08 & 1.28 \\
\hline SD. & 0.20 & 0.51 & 0.49 & 0.49 & 0.74 & 1.08 & 0.46 \\
\hline Median & 2.0 & 2.0 & 2.0 & 2.0 & 2.0 & 2.0 & 1.0 \\
\hline \multicolumn{8}{|l|}{ Control: } \\
\hline Min. & 1.0 & 2.0 & 2.0 & 1.0 & 2.0 & 2.0 & 1.0 \\
\hline Max. & 4.0 & 4.0 & 3.0 & 3.0 & 4.0 & 4.0 & 2.0 \\
\hline Mean & 2.40 & 2.88 & 2.36 & 1.96 & 2.76 & 2.96 & 1.48 \\
\hline SD. & 1.26 & 0.67 & 0.49 & 0.35 & 0.78 & 0.54 & 0.51 \\
\hline Median & 2.0 & 3.0 & 2.0 & 2.0 & 3.0 & 3.0 & 1.0 \\
\hline $\mathrm{H}$ & $7.653^{*}$ & $31.772 *$ & $25.376^{*}$ & $26.022 *$ & $31.821 *$ & $31.058 *$ & $15.162 *$ \\
\hline$p$ & $0.022 *$ & $<0.001^{*}$ & $<0.001 *$ & $<0.001 *$ & $<0.001 *$ & $<0.001 *$ & $0.001 *$ \\
\hline$p_{1}$ & $0.026^{*}$ & $<0.001^{*}$ & $<0.001 *$ & $<0.001 *$ & 0.097 & $0.014 *$ & $0.024^{*}$ \\
\hline$p_{2}$ & $0.011 *$ & $<0.001^{*}$ & $<0.001 *$ & $<0.001 *$ & $<0.001 *$ & $<0.001 *$ & $<0.001 *$ \\
\hline$p_{3}$ & 0.761 & 0.062 & 1.000 & 0.518 & $<0.001 *$ & $0.002 *$ & 0.106 \\
\hline
\end{tabular}

$\mathrm{H}$ and $p$-values for Kruskal Wallis test, pairwise comparison bet.

Each 2 groups was done using Post Hoc Test (Dunn's for multiple comparisons test). p1: $p$-value for comparing between Dex and Bup. 2: $p$-value for comparing between Dex and C. p3: $p$-value for comparing between Bup and $\mathrm{C}$. * : Statistically significant at $p \leq 0.05$.

Dex: Dexmedetomedine group. Bup: Bupivacaine group. C : Control group.
Total dose of post-operative analgesia requirement was significantly lower in Group I (DEX) and Group II (Bup) than in Group III (Control) ( $p$ value $<0.05$ ). Table (2), Fig. (2).

There was no significant difference between the three groups as regard to post-operative side effects as nausea and vomiting.

Table (2): Comparison between the three studied groups according to first request to analgesia and total analgesia per day.

\begin{tabular}{|c|c|c|c|c|}
\hline & $\begin{array}{c}\text { Dex } \\
(n=25)\end{array}$ & $\begin{array}{c}\text { Bup } \\
(n=25)\end{array}$ & $\begin{array}{c}\mathrm{C} \\
(\mathrm{n}=25)\end{array}$ & $p$ \\
\hline $\begin{array}{l}\text { - First request to } \\
\text { analgesia }\end{array}$ & $\begin{array}{l}9.0 \pm \\
3.29\end{array}$ & $\begin{array}{l}1.70 \pm \\
1.0\end{array}$ & $\begin{array}{l}1.04 \pm \\
0.64\end{array}$ & $\begin{array}{l}p_{1} 0.002^{*} \\
p_{2}<0.001^{*} \\
p_{3} 0.011^{*}\end{array}$ \\
\hline $\begin{array}{l}\text { - Total analgesia } \\
\text { per day }\end{array}$ & $\begin{array}{l}30.0 \pm \\
0.0\end{array}$ & $\begin{array}{l}44.40 \pm \\
15.30\end{array}$ & $\begin{array}{l}74.40 \pm \\
15.30\end{array}$ & $\begin{array}{l}p_{1} 0.085 \\
p_{2}<0.001^{*} \\
p_{3}<0.001^{*}\end{array}$ \\
\hline
\end{tabular}

p1: Level of significant between Dex and Bup.

p2: Level of significant between Dex and C.

p3: Level of significant between Bup and C.

*: Statistically significant at $p \leq 0.05$. Bup: Bupivacaine group

Dex: Dexmedetomedine group. $\quad \mathrm{C}$ : Control group.

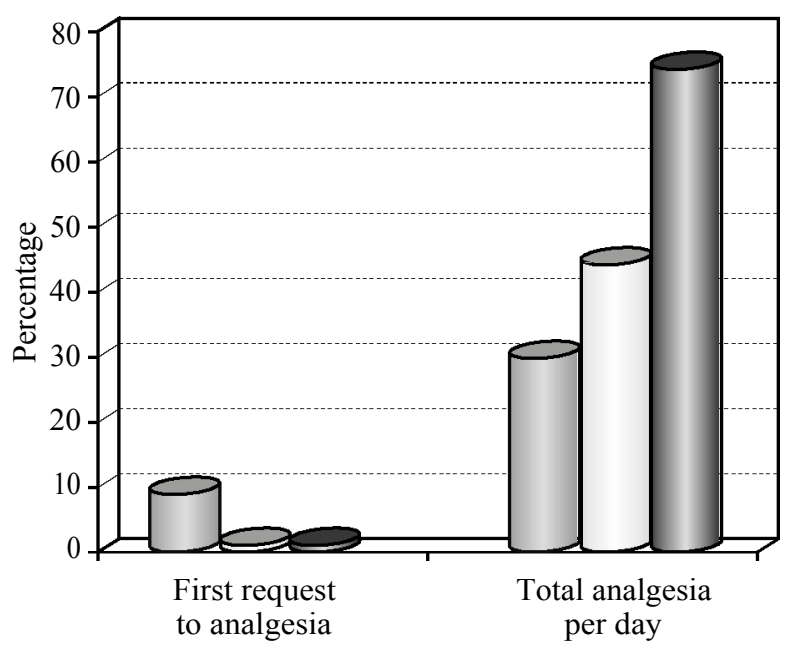

Dexmedetomedine

$\square$ Bupivacaine

Control

Fig. (2): Comparison between the three studied groups according to first request to analgesia and total analgesia per day. 


\section{Discussion}

Despite all the benefits that have emerged with the introduction of LC, post-operative pain remains an issue. Ineffective post-operative pain management may lead to deep vein thrombosis, pulmonary embolism, coronary stress, atelectasis, pneumonia, poor wound healing, insomnia, and demoralization [8]

Although opioid analgesics play an important role in the management of moderate to severe pain, their extensive use during ambulatory surgery may be associated with an increased incidence of postoperative complications [9]

The local anaesthetic agents provide antinociception by affecting nerve membrane associated proteins and by inhibiting the release and action of prostaglandins which stimulates the nociceptors and cause inflammation [7]

The antinociceptive effects of dexmedetomidine occurs at dorsal root neuron level, where it blocks the release of substance $P$ in the nociceptive pathway and through action on inhibitory $G$ protein, which increases the conductance through potassium channels [10]. Bupivacaine is the first local anesthetics that combine the properities of an acceptable onset, long duration of action, profound conduction blockade and significant separation of sensory anesthesia and motor blockade [11]. Visual Analogue Scales (VAS) in different periods over the first $24 \mathrm{hrs}$ in this study showed significant statistical difference between Dex group and control group in all periods assessted and also significant statistical difference between Dex group and Bup group almost over the periods assessted and significant statistical difference between Bup group and control group in delayed periods.

In agreement with our study regarding the effect of Dexmeditomedine, Bakhamees et al., [12] who evaluated the patients who received dexmedetomidine and found that they had less VAS score as compared to placebo in the post-operative period. And with Prakash and Raajaram [13] who found Dexmedetomidine to have significantly better efficacy than tramadol in combination with bupivacaine. The prominent effect of dexmedetomidine may be due to its higher efficacy concids with Rapolu et al., [14] who found that mean pain scores were significantly lower in the Group BD (bupivacaine and dexmeditomedine) when compared to Group B (bupivacaine) during the entire duration of the study and similar results were observed with study done by Ahmed et al., [15] who compared the antinociceptive effect of dexmedetomidine or meperidine with bupivacaine to bupivacaine alone intraperitoneally after the laparoscopic gynaecological surgery found that intraperitoneal instillation of meperidine or dexmedetomidine in combination with bupivacaine significantly decreases VAS score. And Usha Shukla et al., [7]. Intraperitoneal instillation of bupivacaine in combination with dexmedetomidine is superior to bupivacaine alone and may be better than bupivacaine with tramadol.

On the other hand regarding the effect of Bupivacaine in agreement with us Joris et al., [16] and Scheinin et al., [17] could not find statistical significance, but Chundrigar et al., [18] reported that $0.25 \%$ bupivacaine $(50 \mathrm{mg}$ ) reduced the postoperative pain during first $24 \mathrm{~h}$, also Golubovic et al., [19] assessed the analgesic effects of intra peritoneal instillation of bupivacaine in patients undergoing laparoscopic cholecystectomy and came to this result that intraperitoneal instillation of bupivacaine is an effective method for management of pain after laparoscopic cholecystectomy and it significantly reduces post-operative analgesic and antiemetic medication, also Narchi et al., [20] also showed significant efficacy of bupivacaine $50 \mathrm{mg}$ and Szem et al., [21] showed reduced pain scores only for the first $6 \mathrm{~h}$. Mraovic et al., [22] reported the efficacy of $150 \mathrm{mg}$ bupivacaine.

In this study the incidence of shoulder pain was significantly low in groups Dex compared to group Bup. We found that in group Bup 8 patients out of 25 patients and in groups Dex, 2 patients out of 25 patients had post-operative shoulder pain that is comparable to the study done by Ahmed et al., [15] and another study done by Rapolu et al., [14] Prakash and Raajaram [13] found in their study that only $5(12.5 \%)$ patients in Group BD (bupivacaine $\&$ dexmeditomedine) suffered from shoulder pain as compared to $16(40 \%)$ in Group BT (bupivacaine $\&$ tramadol) and $28(70 \%)$ patients in bupivacaine alone group and this comperable to our results.

First request of analgesia found to be delayed in Dex group than Bup and control groups with statistical significance indicating better and longer pain relief in the group Dex compared to other groups, and this in agreement with the study of Rapolu et al., [14] who found that time to requirement of first dose rescue analgesia was prolong in the group $\mathrm{BD}$ (bupivacaine \& dexmeditomedine) (7.61 hours) compared to Group B (bupivacaine) (5.81 hours). And the study of Prakash and Raajaram [13] who found time for first dose analgesia required was significantly shorter in tramadol group than Dexmedetomidine group. 
Total analgesia per day in this study was decreased in Dex group than Bup group and significantly decreased in both groups than control group, comparable also to the study of Rapolu et al., [14] and Also Ahmed et al., [15] who observed that intraperitoneal instillation of meperidine or dexmedetomidine in combination with bupivacaine significantly decreases total rescue analgesia requirement in post-operative period. And near to the results of Rajni Gupta et al., [23] who compared post-operative analgesia with intraperitoneal bupivacaine and fentanyl with bupivacaine after laparoscopic surgery and observed that there is decrease total analgesics consumption in fentanyl with bupivacaine group.

In our study the adverse effects was nausea and vomiting with no statistical significance between the three groups and this comparable to those of Rapolu et al., [14], those of Bakhamees et al., [12] also Fares et al., [24] found the differences in the incidence of nausea and vomiting between the three groups (bupivacaine, bupivacainedexmeditomedine and control groups) in laparoscopic colorectal cancer surgery were statistically insignificant. And those of Usha Shukla et al., [7] who found also there was no statistical significance in side effects in bupivacaine group or bupivacaine and/or tramadol, dexmeditomedine, but in another study with the same medications by Narasimham and Dinakar [25] found Bupivacaine and Dexmeditomedine group have less side effects than Bupivacaine alone group as nausea, vomiting and pruritis.

\section{Conclusions:}

Intraperitoneal instillation of dexmedetomidine 1 kgin elective laparoscopic cholecystectomy significantly reduces the post-operative pain and significantly reduces the analgesic requirement in post-operative period as compared to bupivacaine $0.25 \%$ before removal of trocars at the end of surgery.

Our study does lend support to the use of intraperitoneal local anesthetics in laparoscopic cholecystectomy as part of a multimodal approach to pain management.

We recommend larger series of prospective studies to more accurately account for factors of success for the better techniques and effective use of intraperitoneal local anesthetics in patients undergoing elective laparoscopic cholecystectomy.

\section{Acknowledgments:}

This research was carried out without funding.

\section{Conflicts of interest:}

No conflicts of interest declared.

Authors' contributions:

All authors had equal role in design, work, statistical analysis and manuscript writing.

\section{References}

1- TAE HAN KIM, HYUN KANG, JUN SEOK PARK, IN TAIK CHANG and SUN GYOO PARK: Intraperitoneal ropivacaine instillation for post-operative pain relief after laparoscopic cholecystectomy. J. Korean Surg. Soc., 79: 130-6, 2010.

2- BISGAARD T., KEHLET H. and ROSENBERG J.: Pain and convalescence after laparoscopic cholecystectomy. Eur. J. Surg., 167 (2): 84-96, 2001.

3- JORIS J., THIRY E., PARIS P., WEERTS J. and LAMY M.: Pain after laparoscopic cholecystectomy: Characteristics and effect of intraperitoneal bupivacaine. Anesth. Analg., 81 (2): 379-84, 1995.

4- BAMIGBOYE A.A. and HOFMEYR G.J.: Local anaesthetic wound infiltration and abdominal nerves block during caesarean section for post-operative pain relief Cochrane Database Syst. Rev., (3): CD006954, 2009.

5- S.S. HARSOOR, DEVIKA D. RANI, S. LATHASHREE, S.S. NETHRA and K. SUDHEESH: Effect of intraoperative Dexmedetomidine infusion on Sevoflurane requirement and blood glucose levels during entropy-guided general anesthesia. J. Anaesthesiol. Clin. Pharmacol., 30 (1): 25-30, 2014.

6- EL-LABBAN G.M., HOKKAM E.N., EL-LABBAN M.A., MORSY K., SAADL S. and HEISSAM K.S. : Intraincisional vs intraperitoneal infiltration of local anaesthetic for controlling early post-laparoscopic cholecystectomy pain J. Minim. Access. Surg., 7 (3): 173-7, 2011.

7- SHUKLA U., PRABHAKAR T., MALHOTRA K., SRIVASTAVA D. and MALHOTRA K.: Intraperitoneal bupivacaine alone or with dexmedetomidine or tramadol for post-operative analgesia following laparoscopic cholecystectomy: A comparative evaluation. Indian J. Anaesth., 59 (4): 234-9, 2015.

8- MENTES O., HARLAK A., YIGIT T., BALKAN A., BALKAN M., COSAR A., SAVASER A., KOZAK O. and TUFAN T.: Effect of intraoperative magnesium sulphate infusion on pain relief after laparoscopic cholecystectomy. Acta Anaesthesiol. Scand., 52 (10): 1353-9, 2008.

9- BEAULIEU P.: Non-opioid strategies for acute pain management. Can. J. Anaesth., 54 (6): 481-5, 2007.

10- KAMIBAYASHI T. and MAZE M.: Clinical uses of oc2adrenergic agonists. Anesthesiology, 93 (5): 1345-9, 2000.

11- McLURE H.A. and RUBIN A.P.: Review of local anaesthetic agents. Minerva Anestesiol., 71 (3): 59-74, 2005.

12- BAKHAMEES H. S ., EL-HALAFAWY Y.M. , ELKERDAWY H.M., GOUDA N.M. and ALTEMYATT S.: Effects of dexmedetomidine in morbidly obese patients undergoing laparoscopic gastric bypass. Middle East $\mathbf{J}$. Anaesthesiol., 19 (3): 53 7-51, 2007. 
13- ANURAG YADAVA, SUNIL K. RAJPUT, SARIKA KATIYAR and RAJNISH K. JAIN: A comparison of intraperitoneal bupivacaine-tramadol with bupivacainemagnesium sulphate for pain relief after laparoscopic cholecystectomy: A prospective, randomised study. Indian J. Anaesth., 60 (10): 757-62, 2016.

14- RAPOLU S., KUMAR K.A. and AASIM S.A.: A comparative study on intraperitoneal bupivacaine alone or with dexmedetomidine for post-operative analgesia following laparoscopic cholecystectomy. IAIM, 3 (12): 33-40, 2016.

15-AHMED B., ASHRAF A.E. and DOAA R.: Antinociceptive effect of-adrenoceptor agonist dexmedetomidine vs meperidine, topically, after laparoscpic gynecologic surgery. J. Med. Sci., 8 (4): 400-4, 2008.

16- JORIS J., THIRY E., PARIS P., WEERTS J. and LAMY M.: Pain After Laparoscopic Cholecystectomy: Characteristics and Effect of Intraperitoneal Bupivacaine. Anesth. Analg., 81 (2): 379-84, 1995.

17- SCHEININ B., KELLOKUMPU I., LINDGREN L., HAGLUND C. and ROSENBERG P.H.: Effect of intraperitoneal bupivacaine on pain after laparoscopic cholecystectomy. Acta Anaesthesiol. Scand., 39 (2): 195-98, 1995.

18- T. CHUNDRIGAR, A.R. HEDGES, R. MORRIS and J.D. STAMATAKIS:Intraperitoneal bupivacaine for effective pain relief after laparoscopic cholecystectomy. Ann. R. Coll. Surg. Engl., 75 (6): 437-39, 1993.

19- GOLUBOVIC' S.1, GOLUBOVIC' V., CINDRICSTANCIN M. and TOKMADZIC' V.S.: Intraperitoneal analgesia for laparoscopic cholecystectomy: Bupivacaine versus bupivacaine with tramadol. Coll. Antropol., 33 (1): 299-302, 2009.

20- NARCHI P., BENHAMOU D., BOUAZIZ H., FERNANDEZ H. and MAZOIT J.X.: Serum concentrations of local anaesthetics following intraperitoneal administration during laparoscopy. Eur. J. Clin. Pharmacol., 42 (2): 223 $5,1992$.

21- SZEM J.W., HYDO L. and BARIE P.S.: A double-blinded evaluation of intraperitoneal bupivacaine vs saline for the reduction of post-operative pain and nausea after laparoscopic cholecystectomy. Surg. Endo., 10 (1): 448, 1996.

22- MRAOVIC'B., JURISIC' ${ }^{\prime}$ T., KOGLER-MAJERIC V., SUSTIC A., et al.: Intraperitoneal bupivacaine for analgesia after laparoscopic cholecystectomy. Acta. Anaesthesiol. Scand., 41 (2): 193-6, 1997.

23- GUPTA R., BOGRA J., KOTHARI N. and KOHLI M.: Post-operative analgesia with intraperitoneal fentanyl and bupivacaine: A randomized control trial. Can. J. Med., 1 (1): 1-9, 2010.

24- FARES K.M., MOHAMED S.A., ABD EL-RAHMAN A.M., MOHAMED A.A. and AMIN A.T.: Efficacy and safety of intraperitoneal dexmedetomidine with bupivacaine in laparoscopic colorectal cancer surgery, a randomized trial. Pain Med., 16 (6): 1186-94, 2015.

25- NARASIMHAM M.L. and RAO B.D.: Comparison of intraperitoneal bupivacainealone or with dexmedetomidine or tramadol for post-operative analgesia following laparoscopic cholecystectomy. Indian J. Anaesth., 4 (1): 143 6, 2017.

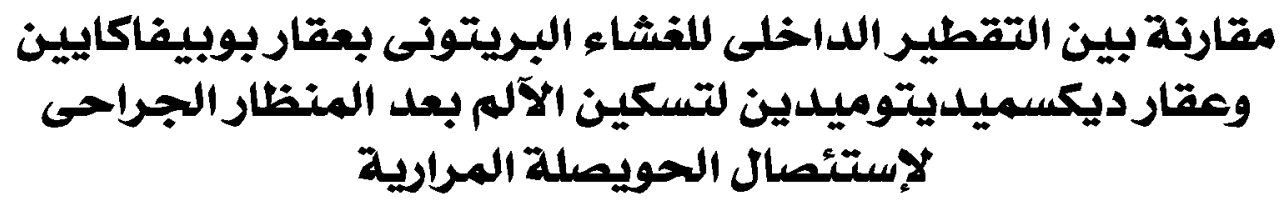

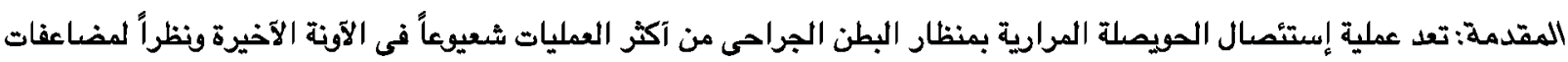

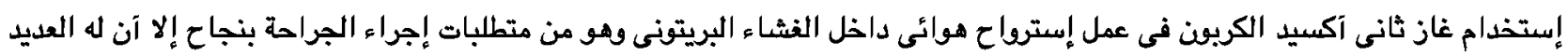

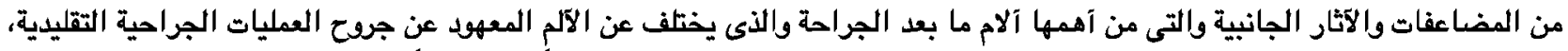

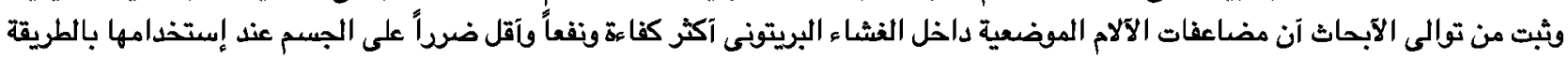
والجرعة والتوقيت المناسب.

ويعتبر الديكسميديتوميدين دواء فعال، وهو إنتقائى للغاية ومحدة لمستقبلات آلفا-ب الآدرينالية، وهو يختف عن الكلونيدين في كونه ستة

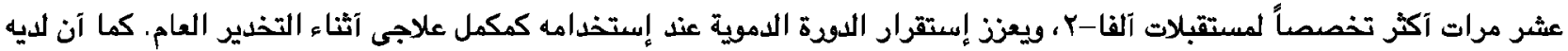

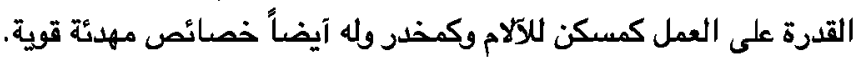

يجب آن يكن العقار المستخدم فى تسكين الآلم بعد العمليات الجراحية ذو كهاءة وقدرة على تسكين الآلم وبتكفة في المتناول ويمتلك آقل

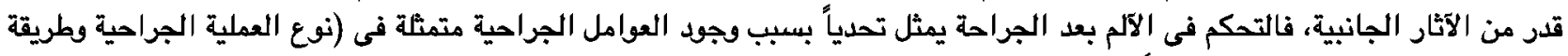

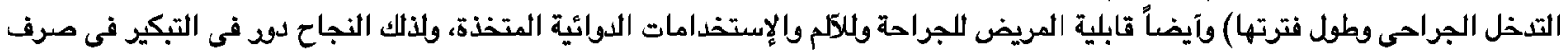

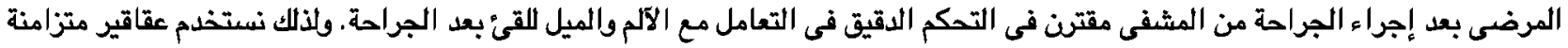

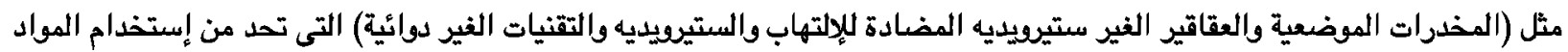


الآنيونية من الممكن آن تمنع حدوث آشهر الآثار الجانبية بعد الجراحة مثل الشلل الوظيفى لحركة الآمعاءوالشعود بالغثيان والقيئ ولذلك تسمح

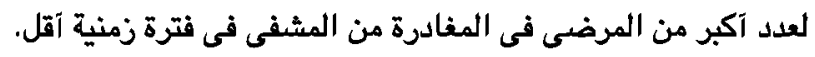
الهدف من الدراسة: المقارنة بين التقطير الداخلى اللغشاء البريتونى من عقار الديكسميديتوميدين وعقار البوبيفاكايين كمسكن لآلام ما بعد جراحة إستئصال العويصلة المرارية بمنظار البطن الجراحى.

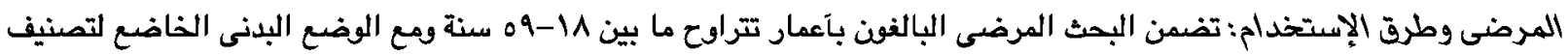

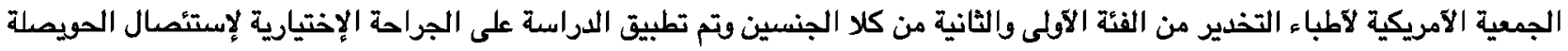
المرارية بمنظار البطن الجراحي. لاءلتير من

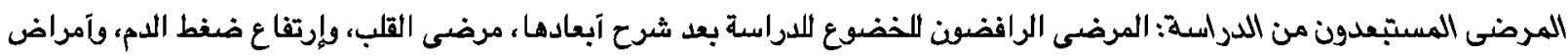

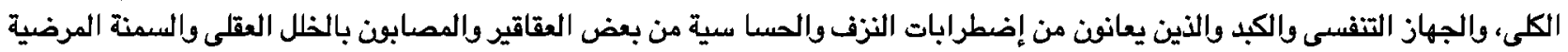

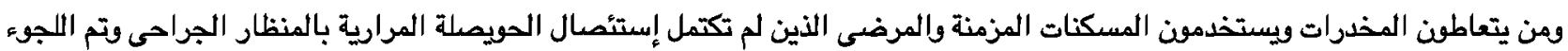

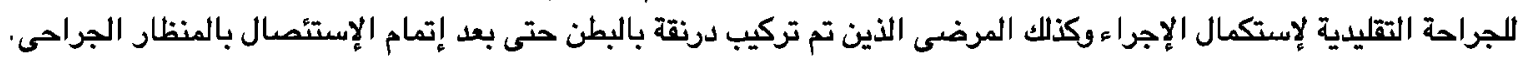
تم إجراء هذه الدراسة فى تسم الجراحة العامة فى مستشفيات جامعة طنطا وشملت هذه الرسالة على Vo مريض وتم تقسيمهم عشوائياً

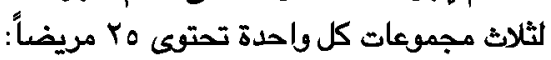
• المجموعة الآولى : خضعت هذه المجموعة واحة إلى التقطير الداخلى اللفشاء البريتونى من عقار الديكسميديتوميدين بجرعة ا ميكروغرام/كغ فى حجم • ممل محلول ملح بعد إتمام الجراحة.

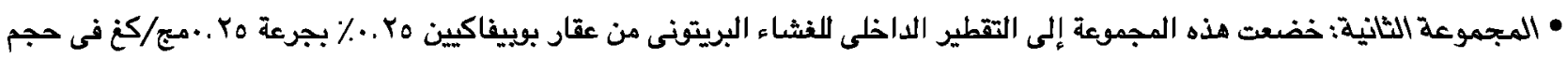
م مل محلول ملع بعد إتمام الجراحة.

• المجموعة الثالثة: خضعت هذه المجموعة إلى التقطير الداخلى اللغشاء البريتونى من محلول ملح بحجم • ممل بعد إتمام الجراحة. تم تسجيل القياسات التالية في المجموعات الثلاث: 1- العلامات الصيوية. r- r r البيانات الديموغرافية.

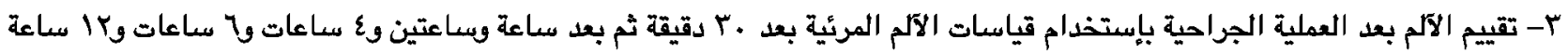
وع ساعة من وقت نزع الآنبوبة الحنجرية وذلك عندما يكن المريض قدا إستعاد وعيه الكامل.

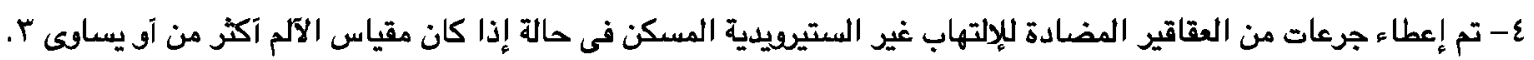

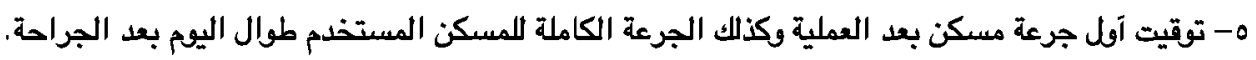

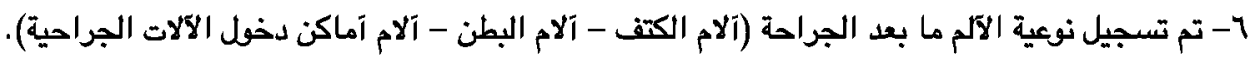
V- V تمجيل المضاعفات والآثار الجانبية.

النتائج: المجموعة الآولمى آفضل من المجموعتين الثانية والثالثة من حيث آلام ما بعد الجراحة وتآخر توقيت آلول جرعة مسكن مطلوية بعد العملية وكذلك كمية المسكن المطلوبة طوال اليوم ونسبة الآثار الجانيية. 